\title{
Fiscal Decentralization and the Business Cycle: An Empirical Study of Eight Federations
}

\author{
Erik Wibbels \\ University of Washington \\ Box 353530 \\ Seattle, WA 98195-3530 \\ P: (206) 616-9315 \\ Fax: (206)-685-2146 \\ ewibbels@u.washington.edu \\ Jonathan Rodden \\ (Corresponding author) \\ MIT \\ Building E53, Room 433 \\ 77 Massachusetts Ave. \\ Cambridge, MA 02139 \\ P: (617) 253-6261 \\ Fax: (617) 258-6164 \\ jrodden@mit.edu
}

Though fiscal policies of central governments sometimes provide modest insurance against regional income shocks, this paper shows that pro-cyclical fiscal policy among provincial governments can easily overwhelm these stabilizing effects. We examine the cyclicality of budget items among provincial governments in eight federations, showing that own-source taxes are highly pro-cyclical and contrary to common wisdom, revenue-sharing and discretionary transfers are either acyclical or pro-cyclical. Constituent governments are thus left alone to smooth their own shocks, even though various restraints on borrowing and saving undermine their ability to do so. These results have important policy implications for Latin America and the European Union.

JEL Codes: H71, H72, H74, H77

Keywords: Fiscal federalism, decentralization, business cycle, stabilization 
The most recent U.S. recession led directly to many state and local governments shedding social workers, teachers, and police officers and cutting social services. While the federal government justified large national deficits with the logic of counter-cyclical Keynsian demand management, state governments partially undermined the potential stimulus with tax increases and expenditure cuts. Only a few years earlier, the states were rapidly expanding their expenditures in conjunction with an unprecedented boom. Similar stories are often told about Latin American countries, many of which have been decentralizing basic health and social expenditures in recent decades. The cyclicality of expenditures in multi-tiered fiscal systems is a key policy issue in the European Union as well, where health and social expenditures are also being decentralized. While national automatic stabilizers might help smooth taxes, consumption, and output over the business cycle, there are strong reasons to expect subnational fiscal policy to pull in the opposite direction, especially as central government clamp down on independent borrowing by subnational governments as part of efforts to abide by the Stability and Growth Pact. Existing comparative empirical research emphasizes the role of national-tax transfer systems in cushioning asymmetric regional shocks, but little is known about the cyclicality of subnational fiscal policy.

These issues motivate the questions of this paper. Are pro-cyclical subnational expenditures simply unavoidable in federations? What explains the degree of subnational cyclicality across countries? To what degree do intergovernmental grants from higher-level governments serve as a stabilizing mechanism for subnational finances? We analyze the sensitivity of provincial government finances to regional business cycles in eight federations: Argentina, Australia, Brazil, Canada, Germany, India, Spain, and the United States. Though a handful of case studies examine the cyclicality of various components of provincial budgets in individual OECD countries, this is the first comparative study. We have chosen these cases primarily because of the availability of high quality provincial-level data with sufficiently long 
time series, but they are useful cases for comparative analysis because they are among the world's most decentralized multi-tiered systems, and because they exhibit analytically useful institutional variation. Above all, we confirm that the finances of constituent units in federations are highly pro-cyclical, yet we also demonstrate interesting cross-national variations and offer a conceptual framework that helps explain them.

In order to explain the cross-national variation, we rely on three features of subnational finance: the income elasticity of regional revenue sources, the role of the central government in stabilizing regional finances (through intergovernmental grants and revenue-sharing schemes), and subnational access to credit markets. The normative fiscal federalism literature has long recognized that subnational governments often have access to rather narrow revenue streams. Indeed, this long has provided the justification for assigning the role of fiscal stabilizer to national governments. Not surprisingly, we find that strongly pro-cyclical revenues-especially from own-source taxes and fees—are the norm among constituent units in federations.

Next we address the tools available to regional governments to smooth expenditures with outside revenue sources from either the central government or credit markets. Given its deeper pockets, broader tax bases, ability to print money, greater freedom from institutional constraints, and wide array of policy tools, the traditional "benevolent government" view of fiscal federalism leads to the expectation that central governments will use intergovernmental grants to dampen the inherent pro-cyclicality of subnational finance, especially when decentralized governments are responsible for the provision of welfare services. Such arguments receive indirect support from a vast empirical literature on the United States and several other countries that focuses on asymmetric shocks to regional income, showing that the national tax-transfer systems shift income toward adversely affected regions. This literature, however, focuses largely on unintended regional consequences of inter-personal tax-transfer policies, and has nothing to say about the budgets of subnational governments and their ability to smooth expenditures over the business cycle. 
In contrast, we outline a political economy perspective leading to the hypothesis that if opportunistic central government officials have discretion over the distribution of grants, they will be positively correlated with the national business cycle, leaving regional governments to smooth shocks themselves as they attempt to externalize the costs of adjusting to revenue shortfalls onto lower-level politicians by cutting grants or introducing unfunded mandates. Central governments will only produce counter-cyclical grants if they can commit to an apolitical allocation process that is explicitly designed to smooth the revenues of constituent units. The evidence presented below supports these propositions, demonstrating that intergovernmental grants are either acyclical or pro-cyclical in most federations. This finding provides a new perspective on the common wisdom that a key function of central government fiscal policy in federations is inter-regional insurance.

In the absence of stabilizing central transfers, regional governments could smooth expenditures by borrowing on credit markets. Thus we hypothesize that where regional governments have relatively unfettered capacity to borrow, expenditures will be less income elastic than in more tightly regulated federations, and only in these federations will it be possible to discern attempts to borrow during downturns. In most federations, prohibitions and administrative controls limit the access of subnational governments to deficit finance, and subnational expenditures are pro-cyclical by design.

Together, the findings in this paper are striking. In most federations — even those with elaborate fiscal equalization programs—subnational governments are, at best, left completely alone to deal with fluctuations in the regional economy. In order to smooth expenditures over the business cycle, constituent governments must rely on their own borrowing and/or saving. The result, more often than not, is profoundly pro-cyclical expenditures. As such, the findings have implications for fiscal federalism in a variety of decentralizing developing counties as well as the EMU—whose members are currently discussing the optimal rules to govern the game of fiscal 
federalism in the future, and where voters have become accustomed to decades of pronounced counter-cyclical public expenditures.

The first section of the paper discusses expectations about the cyclicality of subnational finance drawn from the normative public economics literature, reviews the empirical literature, establishes alternative comparative hypotheses drawn from a political economy framework, and maps the institutional structures of eight federations onto this framework. The next three sections each pursue a different econometric approach to subnational cyclicality across countries, and the final section discusses the results and extracts policy implications.

\section{Federalism, Subnational Budgets, and the Business Cycle}

Since most revenue sources available to governments are highly income elastic, economists have long been concerned with the prospect that fiscal policy will magnify business cycles. In particular, pro-cyclical taxing and spending threaten to exacerbate downturns by disrupting employment and the provision of public services. The impact of such swings in fiscal policy might be particularly severe for a society's most vulnerable citizens if social spending is reduced at times when it is most needed. Musgrave summarized the prevailing view that government has an obligation to fiscal stabilization:

A free economy, if uncontrolled, tends toward more or less drastic fluctuations in prices and employment; and apart from relatively short-term swings, maladjustments of a secular sort may arise towards unemployment or inflation. Public policy must assume a stabilizing function in order to hold within tolerable limits departures from high employment and price stability (1959: 22).

Even if one rejects the Keynsian notion of demand management in a world of policy inertia and rational expectations among market actors, a far-sighted welfare-maximizing government might nevertheless conduct counter-cyclical policy if it acts according to the "permanent income hypothesis," setting government consumption levels according to long-term expectations about income growth rather than yearly fluctuations. A large empirical literature has determined that whatever their motivations, central governments in wealthy countries have behaved in this 
fashion, borrowing and saving so as to smooth the short-term shocks of the business cycle (Arreaza, Sorensen, and Yosha 1999; Tornell and Lane 1999), particularly in Europe (Hallerberg and Strauch 2002). In developing countries, on the other hand, fiscal policy has been either acylical or pro-cyclical (Wibbels 2004).

By contrast, there is considerably less research on budget cyclicality at the subnational level in multi-tiered systems. ${ }^{1}$ This is unfortunate for several reasons. First, the general trend both around the world has been toward greater fiscal decentralization (Rodden 2004). Especially in the world's largest federations, a very large portion of spending, and to a lesser extent taxation, takes place at the subnational level. Second, while fiscal decentralization may be attractive if it improves service delivery and accountability, a growing literature points out that under certain conditions, it may have high costs in terms of fiscal coordination across levels of government (Velasco 2000; Treisman 2000). Nevertheless, no comparative research has examined the role of subnational budget cyclicality as a potential contributor to those coordination problems. Third, despite automatic fiscal stabilizers commonly built into national fiscal policy among EU member states (van den Noord 2000; Brunila, Buti, and in 't Veld 2002), subnational budgets across the world's federations have few such mechanisms. While such stabilizers have worked to dampen the cyclical fluctuations in economic activity by about 40 percent among EU member states (van den Noord (2000: 9), subnational governments have few such policy tools. Indeed, there are good reasons to believe that subnational fiscal policy will be inherently pro-cyclical, including sensitive revenue streams, central government manipulation of intergovernmental grants, and limited access to credit markets.

\section{The pro-cyclicality of provincial revenues}

At any level of government, revenue will be positively correlated with the business cycle unless income inelastic taxes can be used, such as property taxes and sales taxes on food. Even at 
the national level in the EU, where governments have broad tax bases, the evidence suggests that revenues are pro-cyclical. Like central governments, regional governments in federations generally rely on tax flows that are highly correlated with income: taxes on personal and corporate income, sales and turnover, and payroll.

In most federations, moreover, there are reasons to suspect that the tax bases of provincial governments are even more sensitive to the business cycle than those of the center. For starters, provincial governments may be subject to tax competition among regions that constrains the capacity of subnational governments to raise sufficient funds to generate enough savings to combat economic downturns (Norregaard 1997). Moreover, as the normative public economics literature (e.g. Oates 1972) points out, economies of scale in tax collection and redistributive considerations often require that central governments collect the most important taxes. As a result, provinces frequently have few revenue streams at their disposal. The taxes they do control, moreover, tend to be highly responsive to the business cycle. While local authorities often have access to relatively income inelastic property taxes, regional officials are left with income, sales, and in some cases, rollover taxes. Thus we expect to find, quite simply, that countries whose regions are dependent on narrow and income-elastic tax bases will display greater pro-cyclicality.

There is considerable variance in the elasticity of purely subnational tax bases across our cases. In Germany, the Länder have extremely limited “own” taxes-essentially the income inelastic motor vehicle tax-since most taxes are shared across levels (see below). In Spain, recent reforms decentralized the collection of portions of the value-added and sales taxes in order to diminish historically heavy reliance on intergovernmental transfers. In both the United States and Canada, provincial governments have depended for decades upon income and sales taxes for own-source revenue (in addition to a provincial VAT in Canada)—all quite sensitive to the business cycle. In addition to potentially less pro-cyclical revenue sources like excise duties on alcohol and an urban property tax, a sizable share of the own-source revenues of the Indian states

\footnotetext{
${ }^{1}$ For exceptions, see Sorsen, Wu, and Yosha (2001) and Asdrubali, Sorensen, and Yosha (1996).
} 
comes from personal income taxes and a sales tax. The own-source revenues of Australia's states come primarily from a payroll tax, and a small share from property taxes and a series of small, indirect taxes. Argentina's provinces historically have relied on a highly sensitive rollover tax, and Brazil’s states depend heavily on a value-added tax.

Can the center help the provinces smooth their expenditures?

The solution to pro-cyclical provincial revenues in the traditional fiscal federalism literature is to assign the task of stabilization to the central government, which has a broader tax base, the power to print money, and the ability to borrow at lower interest rates. A more recent literature suggests that an important task of a benevolent central government in a large country that experiences stochastic, asymmetric regional shocks is to use fiscal policy to pool risk across regions. The central government in a federation might pursue stabilization either through interpersonal or intergovernmental transfers. In the case of the former, a centralized, automatic interpersonal social insurance program would disproportionately favor the affected region because of the geographic concentration of poor or unemployed individuals. A large empirical literature has demonstrated that central government tax-transfer policies in the United States, Canada, the UK, France, and Italy act to smooth out asymmetric regional shocks. These studies focus on the difference between market (prior to federal tax-transfer) and disposable income, discovering that federal policy provides a modest boost to personal incomes in regions suffering from asymmetric shocks. ${ }^{2}$

These studies say nothing, however, about the second type of central government stabilization. In fact, it is possible that the modest relative income boost associated with national interpersonal tax-transfer policy during an asymmetric regional downturn is completely undone

\footnotetext{
${ }^{2}$ The most influential paper is Sachs and Sala-i-Martin's (1992) study of the United States. Subsequent studies include von Hagen (1992), Melitz and Zumer (1998), Bayoumi and Masson (1995), Obstfeld and Peri (1998), Sorensen and Yosha (1997), van Wincoop (1995), and Brunila, Buti, and in 't Veld (2002). Kletzer and von Hagen (2000) provide a literature review.
} 
by the need for provincial governments to raise taxes or cut expenditures because of flagging revenues. If the typical characterization of subnational governments as fiscally inflexible and credit-constrained compared with the center is correct, the assignment of "stabilization" to the central government in the fiscal federalism literature seems to imply not just interpersonal transfers, but a revenue-sharing scheme or system of inter-governmental transfers that is markedly counter-cyclical to prevent provincially-provided expenditures from vacillating with the business cycle. In the context of the EU, some have assumed that national transfers do indeed serve to insulate subnational budgets from income shocks. Balassone, Fabrizio, and Franco (2002: 32), for instance, suggest that "while at present in most countries (Germany being an exception) sub-national governments' budgets are largely insulated from the effects of cyclical developments, in the future this feature may vanish if more tax bases are assigned to lower government tiers.” The implication is that transfers are at worst unresponsive to the business cycle and at best countercyclical.

Indeed, revenue equalization schemes in federations like Germany, Austria, and Spain, explicitly redistribute revenue from relatively wealthy to relatively poor regions in order to reduce disparities in service provision and/or revenue-raising capacity. But horizontal redistribution should not be confused with insurance against asymmetric regional shocks (von Hagen 1992). Indeed, there is some evidence that national transfers in federations may exacerbate the pro-cyclicality of provincial revenues. Sorensen, Wu, and Yosha (2001), for instance, show that grants from the U.S. federal government to the states are positively correlated with the business cycle. Likewise, revenues flowing to the German states through its tax-sharing scheme are decisively pro-cyclical (Seitz 2000; von Hagen and Hepp 2002). Thus, automatic transfers may do little to smooth regional fiscal cycles. Inter-personal flows usually smooth out asymmetric shocks in a relative sense-i.e. extra resources shift from Bavaria to Bremen after a shock to the shipbuilding industry—but this does not mean that Bremen's expenditures on 
unemployment, welfare, and personnel can necessarily increase or even stay flat in the face of rising unemployment and declining growth.

The literature, moreover, has paid very little attention to symmetric shocks. Though it is not entirely clear, the normative fiscal federalism view seems to suggest that flows from the center to the states should counteract symmetric shocks as well. If the own-source revenues of provincial governments are pro-cyclical, and they are major public sector employers and the primary providers of education, unemployment, health, and welfare benefits, presumably the assignment of stabilization responsibilities to the central government requires that the center use its deeper pockets to borrow on behalf of regions and bolster their revenues through increased transfers in the face of a country-wide recession.

Yet there are good reasons to believe that counter-cyclical flows from the center to the constituent units are not compatible with the central government's incentives. Since tax increases and expenditure cuts are politically painful, central governments will face incentives to externalize the costs of adjustment onto subnational officials. To the extent that central governments borrow to smooth expenditures, election-motivated governments will be more inclined to borrow in order to maintain the path of their own expenditures, for which they can directly claim electoral credit, than those of subnational governments. If resources are severely constrained and further borrowing is costly, the center might even be tempted to shift some of its responsibilities to the constituent governments without providing additional funding-perhaps even cutting existing funding. Such so-called “unfunded mandates” are the common complaint of constituent governments in virtually every federation around the world, and the complaints seem to grow loudest during recessions. It is difficult to identify the effect of unfunded mandates with data analysis. Yet one simple hypothesis is that intergovernmental grants, to the extent that the center has discretion, will be pro-cyclical, especially in response to negative shocks because of the center's incentives for opportunistic burden-shifting. Furthermore, we hypothesize that the only situation in which grants will be counter-cyclical is one in which the center has delegated 
authority over grants to an independent agency with an explicitly counter-cyclical mandate. ${ }^{3}$ The only examples of this among our cases are Australia, and to a lesser extent, India.

\section{Can provinces smooth expenditures through borrowing?}

If own-source and transferred revenues are pro-cyclical as we suspect, provincial governments will only be able to smooth expenditures by borrowing. Yet in many federations, self- or centrally-imposed rules place limitations on borrowing. The constitutions of the German states impose a "golden rule" that requires them to borrow only for capital expenditures, though the line between capital and current is extremely porous, and some states have simply ignored their constitutions. All but one U.S. state has some sort of balanced budget rule, though it is important to stress that these are enforced not by the central government, but by state courts and voters. Though the system is transitioning away from central oversight, for most of the postwar period the Australian central government has undertaken borrowing on behalf of the states, and the distribution of loans among the states has been determined by an autonomous commission. In India, the federal government must approve borrowing by the states and imposes limits on states that are debtors to the center (in practice this means all states). In Argentina, the privatization of provincially-owned banks and a number of intergovernmental agreements in the 1990s served to somewhat constrict a system that previously left provinces wide leeway in borrowing domestically and even abroad. In Brazil, the federal government has made various attempts to restrict the borrowing of states, though enforcement was quite poor throughout the 80s and 90s. In Spain, the autonomous communities historically have had access to credit markets with only poorly enforced restrictions, though recent reforms aim to impose more rigorous balanced budget requirements on them. The only country in this study with essentially unlimited access to credit

\footnotetext{
${ }^{3}$ There is yet another reason to expect pro-cyclical grants. Some countries use matching grants. In an effort to encourage spending by subnational governments in areas characterized by positive externalities, central governments sometimes offer to match provincial spending up to some limit. Though provinces are
} 
markets among the constituent units is Canada, where all of the provinces borrow substantially in international credit markets. ${ }^{4}$

Considerable research points to the importance of balanced budget laws (Alt and Lowry 1994), constitutional limitations on borrowing and indebtedness (Poterba 1996), and caps on expenditure growth (Alesina and Bayoumi 1996) as useful formal checks on the capacity of regional politicians to generate fiscal imbalances. Indeed, researchers have exploited the crosssectional variation in the rules of the U.S. states, and most have concluded that the states with stronger rules run smaller deficits, receive higher bond ratings, pay lower premiums, and adjust to shocks more quickly (Alesina and Bayoumi 1996; Poterba and von Hagen 1999; Poterba 1994). In the context of the EMU, such evidence has contributed to a trend in favor of centrally-imposed fiscal restrictions on subnational governments.

Nevertheless, whether borrowing limitations and other rules-based approaches actually affect subnational fiscal decisions is still a matter of some debate. Subnational governments have many ways of getting around borrowing restrictions, including off-budget accounts, generous interpretations of capital expenditures, and abuse of state-owned enterprises and banks. Moreover, in many cases the enforcement mechanisms are weak or non-credible. Indeed, most domestic stability pacts among EU member states have very weak procedures for sanctioning over-spending regions.

This paper will not resolve the debate, but if these rules have some effect, they will prevent provincial governments from smoothing negative shocks. That is, we expect cyclicality to show up on the expenditure side as well as revenue side in the presence of borrowing restrictions. We have no basis on which to compare the likely restrictiveness of U.S. balanced budget rules with German "golden" rules, the allocations of the Australian and Indian loan

likely to make cuts during recessions in areas that are not subject to matching, it is possible that some matching funds will be lost if provinces are forced to make cuts in these areas.

${ }^{4}$ Very recently, after the end of our data coverage, some Canadian provinces have introduced new fiscal restrictions, though most experts are skeptical about the likelihood of enforcement. 
commissions, or the Latin American attempts at regulation. The only straightforward hypothesis, then, is that among our cases, the more restricted the access to credit markets, the more procyclical fiscal policy will be. Counter-cyclical public expenditures are most plausible where provincial authorities have unimpeded access to credit markets (Canada), less so where access to credit is constrained by either budget rules (the U.S. and Germany) or central authorities (Australia and India), and least likely where credit is only sporadically unavailable or irregularly so (Brazil and Argentina). ${ }^{5}$

\section{Empirical expectations}

To recap, we expect to find that own-source provincial revenues are pro-cyclical in all federations, especially in countries that rely most heavily on income-elastic taxes. Similarly, though formulaic revenue-sharing programs are likely to provide some horizontal insurance against asymmetric income shocks, the underlying pro-cyclicality of the shared tax base will make for pro-cyclical or at best acyclical flows of shared revenue. For discretionary grants that can be altered by the central government in the yearly budget process, we expect that opportunistic burden-shifting will be manifested in pro-cyclicality, particularly when shocks are negative. This adds up to highly pro-cyclical revenue streams. Because of borrowing limitations, we expect that provinces in most countries, except perhaps Canada, will find it difficult to fully offset this pro-cyclicality through borrowing.

\section{A Static Approach}

\footnotetext{
${ }^{5}$ The recent literature on subnational "soft budget constraints" points out that in some contexts, subnational officials expect the central government to be unwilling or unable to resist demands for bailouts when their debt burdens become unsustainable. If subnational officials hold such beliefs, set expenditures according to long-term revenue expectations, and have access to deficit finance, they may be more willing to take on debt than subnational governments that do not have bailout expectations. It is also the case, however, that such soft budget constraints are endemic in cases where national and subnational governments have limited access to credit markets during recessions (i.e. developing nations). That being the case, there might be some overall public sector budget constraint that reinforces subnational pro-cyclicality.
} 
We have collected yearly data on revenues, expenditures, deficits, and gross state product for each state or provincial government in eight federations around the world. Moreover, we have broken the revenue data down into grants and own-source provincial revenues (primarily taxes, but this category also includes user fees, income from state-owned enterprises, etc.) and grants. Because the hypotheses above distinguish between formulaic and discretionary transfers, we would also like to disaggregate grants into two components. We have only been able to do this for the Latin American and Indian cases, where the distinction between "coparticipation” and other more discretionary transfers is easy to make in the data. ${ }^{6}$ With the exception of the Spanish case, the expenditure data include both capital and current expenditures. We have consulted country experts in each case and used the most appropriate deflator (either CPI or GDP implicit price deflator), along with yearly population estimates to obtain real per capita income and fiscal data. $^{7}$ We have collected the longest possible consistent time series for each country. The best coverage is for Canada, which begins in 1968. The worst is for Australia, which because of a change in accounting regimes only covers 12 years beginning in $1990 .^{8}$

Thus for each country, we have panels of yearly inflation-adjusted per-capita fiscal and income observations for each province. Complete Indian data are only available for the so-called "major states," and we only include the "old” western states of Germany. We have conducted extensive tests for the influence of outliers, guided both by post-estimation residual plots, knowledge of the cases, and reviews of each country's empirical literature. The most important considerations appear to be dependence on natural resources and the special status of capital cities. We exclude Alaska and the District of Columbia from the U.S. regressions, the Northern

\footnotetext{
${ }^{6}$ The German yearly data do not allow us to distinguish between tax revenues obtained through shared taxes and the miniscule taxes actually controlled by the individual Länder. The variable called "grants" in the analysis below refers to a combination of the grants distributed by the Bund in the third stage of the equalization process and various other shared-cost and federally-funded programs.

${ }^{7}$ In Germany, Canada, and India it was possible to use province-specific deflators, while for the other cases we were forced to use national-level price data.

${ }^{8}$ Coverage is as follows: USA 49 states 1977-1997, Canada 10 provinces 1968-1997, Germany 10 Länder 1974-1995, Australia 6 states and the Australian Capital Territory 1990-2001, Spain 17 autonomous
} 
Territory from the Australian regressions, Berlin from the German regressions, the Federal District from the Brazilian regressions, and the city of Buenos Aires from the Argentina regressions. Only in the cases of Alaska and the Northern Territory (Australia) does the exclusion affect the results substantially. ${ }^{9}$ The results below are not affected by the exclusion of other Western U.S. states that depend heavily on natural resources, nor are they affected by the exclusion of Alberta from the Canadian regressions, or the rather unique city-states of Bremen and Hamburg from the German regressions.

We conduct separate regressions for each fiscal item in each country. In most countries, the expenditure, revenue component, and gross state product data demonstrate pronounced upward trends, and unit root tests often indicated non-stationarity. Thus for the expenditure and revenue models, all variables are measured as deviation from logged per capita trend values. The trend value was calculated using the Hodrick-Prescott smoothing filter, and the difference between the real and trend value was taken as a percent of trend. Since the per capita surplus/deficit data are clearly stationary, we examine the response of the budget balance to the business cycle by simply regressing the first difference of the logged per capita surplus on the first difference of logged per capita provincial income. Note that very similar coefficients are obtained, however, if we use the same deviation from trend method as for the other variables. More generally, with only a few minor exceptions, our results are quite similar using a variety of other estimation techniques. In all cases, we report the results of fixed effects regressions with panel-corrected standard errors, correcting for first-order autocorrelation of residuals, and assuming the disturbances to be heteroskedastic and contemporaneously correlated across panels.

For each regression, we report results both with and without a panel of year dummies, each with a different interpretation. Models that include year dummies control for common

communities 1984-2001, India 14 states 1980-1998, Brazil 26 states 1986-2000, Argentina 23 provinces 1980-2001.

${ }^{9}$ When Alaska and NT are included, the pro-cyclicality of both revenues and expenditures is more pronounced. 
shocks experienced by all states in a particular year-for example a symmetric downturn in the national economy or a change in federal macroeconomic policy that has symmetric effects on all states. As a result, such models hone in on the effects of asymmetric provincial income shocks. However, many of the arguments explored above, particularly those relating to unfunded mandates and strategic burden-shifting, require that the year dummies be left out so that symmetric national shocks—say a common negative shock accompanied by unfunded mandates-are allowed to affect the results. In order to draw policy implications, it is probably also more useful to understand the impact of absolute rather than merely relative economic shocks.

\section{[TABLE 1 HERE]}

The results are presented in Table 1 . Each cell in the table is the coefficient from a separate regression, and represents the income elasticity for each budget item. In order to help the reader wade through the results, rather than presenting standard errors, we simply leave the cells blank where the coefficient is clearly indistinguishable from zero (our cut-off is p>.25) and indicate statistical significance with asterisks. For each revenue item and for expenditures, a positive coefficient represents a positive, or pro-cyclical, correlation with gross state product. However for the surplus, a positive coefficient reveals that governments increase the surplus during good times and/or decrease it (enlarge the deficit) during bad times, which is consistent with counter-cyclical borrowing and saving.

As expected, the first column reveals that overall provincial revenues are highly procyclical in all federations. In the models without fixed effects, with only a couple of exceptions the coefficients approach or even surpass 1 . Note that in the case of Spain these and the following results are not an artifact of significant decentralization in the 1980s-the results are essentially 
unchanged if the sample is constrained to 1990 and beyond. ${ }^{10}$ The next column reveals that these large coefficients are driven primarily by severely pro-cyclical own-source revenues, whichIndia aside-are considerably more income elastic than overall revenues. Indeed, most of the coefficients surpass 1 .

Perhaps the most intriguing coefficients are for grants. These results should put to rest any perception that intergovernmental grants are broadly countercyclical. Above all, there is not a single negative coefficient for any model without year dummies. For the U.S., Canada, and Germany, it is interesting to note that the coefficient is positive in the model without year dummies, and negative when the dummies are included. Using a shorter time series, Sorensen, Wu, and Yosha (2001) find a similar relationship for the U.S. states. Grants apparently are counter-cyclical only if common shocks are suppressed through year dummies. A reasonable interpretation is that progressive intergovernmental transfer programs provide a relative shift of resources towards states suffering from asymmetric negative shocks. However, this does not help combat the overall pro-cyclicality of state revenues. When common shocks are allowed to affect the results, grants are positively correlated with the business cycle. The coefficients for grants are positive and significant in Spain in the model that excludes year dummies, while in Australia the same holds in the model that includes year dummies. In Argentina and Brazil transfers are clearly pro-cyclical regardless of whether shocks are asymmetric or not. Only in India, with its independent grants commission, do grants not exacerbate problems with regards to common shocks. For Argentina, Brazil and India it was possible to conduct separate analyses of revenuesharing receipts and discretionary grants. In both Argentina and Brazil, discretionary transfers behave consistent with our opportunistic characterization of central governments. ${ }^{11}$

\footnotetext{
${ }^{10}$ Only in the model for grants does constraining the sample matter. In that case, the coefficient shrinks by about half and falls just below significance.

${ }^{11}$ In Brazil, the progressivity of coparticipation payments creates what looks like an inter-regional insurance effect. However, discretionary transfers are positively correlated with the business cycle and the coefficients are quite large. In Argentina, even automatic transfers fail to provide an insurance effect, but
} 
Next, we examine whether these largely pro-cyclical revenues translate into pro-cyclical expenditures. The answer is yes in all countries but Australia. Expenditures in Brazil and Spain are severely pro-cyclical in the absence of year dummies-a one percent increase in regional GDP per capita above trend is associated with almost a two percent increase in real expenditures per capita. The coefficients for Germany and India are also impressively large. Expenditures are procyclical in Canada in the absence of year dummies, and quite surprisingly, counter-cyclical in Australia, though the coefficient is not significant. The Australian results are quite sensitive given the short time series and small number of states. On the whole, the positive coefficients in the expenditure column are quite striking when compared with the results of EU studies of central governments, where expenditures are decisively counter-cyclical. Hallerberg and Strauch, for instance, estimate the income elasticity of expenditures in the EU at -.36 in the absence of time effects. $^{12}$

The positive, significant coefficients in the surplus column suggest that the U.S. states, Canadian provinces, and Australian states all attempt to smooth income shocks by borrowing during bad times and possibly saving during good times, though the coefficient for the United States is very small. Though a one percent decrease in real GSP per capita is associated with a .68 percent decrease in per capita revenue, it is only associated with a .05 percent increase in the per capita deficit. By contrast, the income elasticity of the surplus in European countries is somewhere around .36. Whether constrained by their balanced budget rules or conservative voters, the U.S. states are loath to use borrowing or "rainy day funds" to smooth income shocks, and their expenditures are pro-cyclical as a result.

As expected, the Canadian provinces, with their unfettered access to international credit markets, seem to make stronger attempts to smooth shocks. The "surplus" coefficient is .13 in the model without year dummies, and .22 in the model with year dummies. Perhaps surprisingly, the

discretionary grants are much more pro-cyclical than automatic transfers in the presence of asymmetric shocks. 
coefficients for the Australian states are even larger: .20 and .48. In both cases, these results more closely approximate those for OECD central governments than those for the U.S. states.

In Germany the surplus coefficient is positive but insignificant in the absence of year dummies. The most we can say is that Land surpluses are acyclical, though it is worth keeping in mind that expenditures are strongly pro-cyclical. The surplus coefficients are rather sensitive; in fact Rodden (this volume) argues that fiscal management varies a great deal across states depending on bailout expectations. As with the German case, there may be problems with pooling the constituent units in Brazil, Argentina, and India when incentives and access to deficit finance vary dramatically across units. That said, the deficits of the Brazilian and Indian states and Argentine provinces are acyclical while expenditures are decisively pro-cyclical, and these results are essentially the same among smaller subsets of states and provinces. Though much has been written about the role of intergovernmental bailouts in these cases, which one might expect would allow for counter-cyclical expenditures, we believe the findings are a function of two factors: the profound depth of business cycles and the limited capacity of governments at all levels of government to borrow during recessions. ${ }^{13}$

Perhaps most interesting are the results for Australia states and Spanish regions, where the surplus/deficit moves with the business cycle in a way that indicates smoothing. Again, it is worth noting that the Spanish results are not being driven by the significant process of decentralization in the 1980s as the basic results change little when the model is rerun only for the 1990s. The result for Spain is consistent with historically weak oversight of regional borrowing, which has contributed to recent reforms to intergovernmental and regional fiscal systems. Australia is the only country under analysis with a negative coefficient on the expenditures side. It is difficult to know what to make of this result given the small number of observations and the fact that the system governing borrowing among the Australian states has been in flux during the

\footnotetext{
${ }^{12}$ With time effects, their coefficient shrinks to -.15.

${ }^{13}$ See IMF (2003) on the volatile supply of credit to developing nations.
} 
period under analysis. However, it would appear that the allocations of the Australian Loan Council have explicitly encouraged borrowing to smooth shocks.

\section{Differentiating between positive and negative shocks}

It is worthwhile to examine whether some of the results above are driven disproportionately by positive or negative shocks, or whether perhaps some interesting relationships have been masked by suppressing possible asymmetric responses. To do so, we create separate variables for those years when actual output exceeds trend (a positive shock) and falls short of trend (a negative shock), where the trend is calculated as above. The positive shock variable is 0 for all years in which income falls below trend, and vice versa. We use the same estimation techniques as above. Table 2 reports the results, again leaving the cells blank where $\mathrm{p}>.25$.

\section{[TABLE 2 HERE]}

Though it is difficult to generalize across all of the models, for the most part regional governments demonstrate stronger responses to negative output shocks than positive ones. However, the coefficients for grants reveal some interesting relationships. First of all, recall the positive but statistically insignificant coefficient for grants in the U.S. regression without country dummies above. Table 2 reveals that while there is no significant response to positive shocks, negative shocks are correlated with cuts in federal grants. The interpretation of a positive coefficient for the "negative shock" variable is no different than in Table 1-income and grants move together. The more negative the shock, the smaller the per capita grant. The same holds for symmetric shocks in India, though in that case, grants are also counter-cyclical in response to positive shocks. Both of these cases are consistent with our story about opportunistic burdenshifting. Germany, Spain, Brazil, and Argentina all show signs of pro-cyclical responses of grants to positive income shocks-grants increase when the economy improves. Only in two cases-Germany and Canada—is there any evidence that grants serve the stabilizing role 
implicitly prescribed in the fiscal federalism literature, though even in these cases, the effect is present only when year dummies are included and symmetric shocks are thus ignored. As discussed with regards to the previous Table, the interpretation is that progressive intergovernmental transfer programs in Germany and Canada provide a relative shift of resources towards states suffering from asymmetric negative shocks but do little to alleviate the overall plight of regional governments in the event of a common shock.

Next, note that the discretionary grants in the Latin American federations and India are much more pro-cyclical than non-discretionary co-participation programs. While automatic grants during negative shocks appear to be somewhat counter-cyclical in Argentina (in the presence of year dummies) and slightly pro-cyclical in Brazil, discretionary transfers are quite pro-cyclical in Argentina, Brazil, and India. Note, however, that the pro-cyclicality results from different phases of the business cycle in Argentina as opposed to Brazil and India. Discretionary transfers are dramatically curtailed in response to negative shocks in India and especially Brazil, while in Argentina, such grants grow disproportionately during good times.

An examination of the expenditure results also yields some clarifications of previous findings. First, consider the United States, where we see that most of the pro-cyclicality of expenditures in the model without year dummies comes from retrenchment during bad economic times. A similar story holds in Canada, where expenditures are strongly pro-cyclical in the model without year dummies. The opposite holds for the German states, where expenditures surge in good economic times and hold steady during downturns (in the model without year dummies). The same holds for Spain where all of the cyclicality in expenditures results from increases in response to positive shocks. The Brazilian results suggest severe pro-cyclicality both in good times and bad whether symmetric shocks are dummied out or not.

Finally, the results with regards to the surplus model tell a fairly consistent story across countries. In all cases where surpluses are counter-cyclical, that counter-cyclicality is driven disproportionately from borrowing in bad times rather than saving during good times. Several 
countries do show signs of attempting to combat the business cycle through borrowingt during bad economic times. Such is particularly the case for Canada, Australia, Germany (only in the presence of common shocks), and Spain (only when controlling for common shocks). In Germany and Spain, constraints on borrowing have been weakly enforced while in Canada, governments have reasonably free access to credit markets. During the period under analysis, Australia has been transitioning from a system of centrally allocated credit to a market-based system. Not surprising given their balanced budget amendments, the U.S. states show only modestly counter-cyclical deficits in response to downturns.

The key results of these two sections are easily summarized. There are very few negative coefficients for expenditure and revenue items. Pro-cyclicality is the rule among provinces and states in federations. Own-source and total revenues are always highly pro-cyclical. When they are non-discretionary, grants show fleeting evidence of playing an inter-regional insurance role, shifting additional resources to states that suffer from asymmetric negative shocks. But when common income shocks are considered, grants are either acyclical or pro-cyclical where the central government has no discretion over grants, and in the cases where the central government most clearly has discretion, grants are unmistakably pro-cyclical, especially during downturns. The subnational units with freer access to credit markets do increase borrowing during bad times, making expenditures less sensitive to the business cycle than revenues, but only in Australia—-the case with the fewest data points—are expenditures not clearly pro-cyclical.

\section{A dynamic approach}

An alternative approach to the static approach taken thus far is to examine the dynamic reaction of budgets to innovations in provincial economies by using lagged levels of GSP per capita. This step has a number of advantages. First, we expect that economic shocks have budgetary implications over a number of years. A sharp contraction in income this year, for instance, is likely to reduce revenues for a number of years to come. Second, it is possible that the 
cyclical properties noted above are very short-term and therefore less problematic than if the effects were very persistent through time, which would raise concerns about the possibility that subnational taxing and spending exacerbates the business cycles. Additionally, we expect interesting differences across federations in how budgetary components respond to economic changes through time. There is evidence, for instance, that revenues in the U.S. states are quickly affected by economic shocks, while expenditures move more slowly (Sorensen, Wu, and Yosha 2001). The net result is a tendency toward consistent (if small) surpluses (deficits) over several years in the presence of a positive economic innovation (deterioration). Consistent with the "voracity effect”, however, we expect provincial governments in Argentina and Brazil to be politically incapable of running surpluses. In contexts of volatile tax bases and political clientelism, the pressure to increase spending at once in response to positive economic shocks is likely irresistible. When combined with a history of profoundly soft budget constraints and scarce credit during recessions, the result should be that income shocks will produce similar effects for both revenues and expenditures in such cases, thus eliminating the potential for smoothing.

To investigate the dynamic response of provincial budgets to provincial income, we regress per capita real state surpluses, revenues, and expenditures on real gross state product per capita and four lags. The models also include a panel of dummies for fixed provincial effects, but do not include year dummies. ${ }^{14}$ Since both revenues and expenditures are non-stationary, we do not present parameter estimates. Consistent with Sorensen et al. (2001), we graph the predicted effect of a 1 percent permanent increase in GSP on the budget components over the five-year period. ${ }^{15}$ The graphs present the real change in national currency units to budget components of an identical percent increase in income across provinces in the eight countries. As a result, the

\footnotetext{
${ }^{14}$ The inclusion of year dummies yields broadly similar results. The most notable difference is the tendency for revenues and expenditures to revert to the mean more quickly when controlling for national shocks.

${ }^{15}$ The 1 percent was calculated as a share of average provincial GDP for the most recent year available. For instance, in the U.S., the average state GSP in 1997 (the most recent in our data set) was \$29,123.09. A one percent increase in this case amounts to $\$ 291.23$ To generate the graphs we calculate the accumulated
} 
shapes of the graphs are directly comparable across cases, allowing us to examine how budgetary components move in each national setting. Given different national currencies, however, the scales of the changes are not themselves comparable.

\section{[FIGURE 1 HERE]}

Figure 1 shows some similarities across all nations. Most notably and consistent with the findings above, both revenue and expenditure tend to increase (decrease) over the course of the five year period after a permanent increases (decrease) in provincial income. In no case does either budget category revert to the mean by the end of the period.

This broad similarity aside, the graphs show countries that follow one of two patterns. In the first, which include the United States, Canada, Spain, and Australia, provincial revenues climb (fall) sharply in the initial year in which GSP increases (falls), with expenditures reacting more slowly through time, though at varying speeds across these countries. The result is that the surplus or deficit plays a smoothing role in these cases, reverting to zero after between two (Australia) and five (Canada) years. In the U.S., expenditures draw near revenues after four years. Only in the Spanish case does the shock result in a long-term surplus or deficit. In Canada, Spain, and the U.S., the fiscal response is quite slow and smooth, occurring gradually over the course of the entire five-year period. In Australia, on the other hand, spending reacts sharply in the second year after the increase in GSP, returning quickly to balanced budgets.

The second pattern includes the German, Brazilian, Argentine, and Indian cases. Unlike the dynamic described above, here revenues and expenditures move together very closely. Note that the difference is not on the revenue side-like the U.S., Canadian, Spanish and Australian states, regional governments in these cases display a sharp revenue response in the initial year of the income innovation. Indeed, the Brazilian states and Argentine provinces are noteworthy for the very strong response of revenues in the first year. These four cases are quite different,

predicted value of the budget component on the basis of the coefficients from the regression of the budget category on GSP and four lags. 
however, on the expenditure side, where spending responds immediately rather than more smoothly, and the deficit responds very little in the initial years in Germany and Argentina, and not at all in Brazil and India.

Two potential explanations to these latter findings present themselves. The first is the aforementioned voracity effect. Tornell and Lane (1999) suggest that in societies with weak institutional foundations and politics that rely on fiscal redistribution, powerful interest groups will consume all of an unexpected fiscal windfall. In such contexts, politicians find it impossible to resist the siren call of spending. Though probably informative with regards to the Brazilian, Indian, and Argentine contexts, such an argument provides less insight into the behavior of the German Länder. A more generalizable explanation may lay with the aforementioned discussion of soft budget constraints and dependence on federal largesse. It is noteworthy that all four of these cases have seen considerable fiscal bailouts of provincial governments by their national counterparts. Of course, the Brazilian and Argentine cases are in a league unto themselves on this account, but a pair of small Länder in Germany have also benefited from post hoc rescues, while others may hope for the same. In India, the national government has used ad hoc transfers and bailouts of deficit-laden state electric companies as a means to relieve fiscally stressed states. Under these soft budget constraints, there are no incentives for provincial governments with bailout expectations to save since the bailouts provide more benefits to the most troubled provinces. Any province that fails to increase spending in response to a positive revenue shock would produce surpluses that undermine its capacity to attract future bailouts. By the same token, however, one might expect that states with bailout expectations would be slow to reduce expenditures in response to negative shocks. In the developing country cases, the lack of borrowing during downturns is likely shaped by credit constraints. The lack of more pronounced expenditure smoothing in the German case is more mysterious; in spite of loopholes and access to easy credit through state-owned banks, the German Länder appear on the whole to abide by their constitutional "golden rules” outlawing borrowing to smooth current expenditures. 
The general findings in this section dovetail with the previous results. In federations where provincial governments approximate sovereigns as they do in Canada, the U.S., and perhaps increasingly Australia, they are able to engage in some level of smoothing over the business cycle, though expenditures remain pro-cyclical. In contrast, where provincial revenues, access to credit, and bailouts depend on the center, provincial fiscal policy is more strongly procyclical.

\section{Conclusions}

Subnational finance in several of the world's most decentralized federations is overwhelmingly pro-cyclical. Given the near universal pro-cyclicality of revenues and expenditures and the lack of intergovernmental grants with insurance effects, it appears that the recent recession-induced tax increases and expenditure cuts of U.S. state governments are the rule rather than the exception. And while the constituent governments in the OECD federations under analysis do show signs of responding to negative shocks with increased budget deficits, in no case does this clearly translate into counter-cyclical expenditures. In most federations, it would seem that provincial fiscal policy is often pro-cyclical by design, raising questions about the capacity of general governments to combat the business cycle in decentralized multi-tiered fiscal systems. Particularly where provincial governments are responsible for social policies and poverty alleviation programs, for which demand increases during bad times, this has implications for the poor and unemployed.

Moreover, despite the normative fiscal federalism literature and possible misinterpretations of recent empirical literature, there is very little evidence that federal governments use intergovernmental grants to smooth regional economic shocks. In fact, in many cases, when common shocks are allowed to affect the results, grants are positively associated with the budget cycle. Closer examination of the data suggests that this results from the tendency of national governments to cut grants in response to negative economic shocks. Such is particularly 
the case when grants are distributed at the discretion of national leaders. These results provide compelling evidence for a political economy interpretation of intergovernmental finance whereby national officials find it easier to shift fiscal burdens onto subnational governments than engage in retrenchment themselves. Anecdotal evidence from recent U.S. and German downturns suggests that the burden of adjusting to negative shocks may cascade even further down, as state and provincial governments attempt to balance their budgets by shifting responsibilities and cutting grants to local governments and school districts.

These findings have implications for ongoing debates in the European Union. Key characteristics of several of the more decentralized member states suggest that the levels of pro-cyclicality observed in our cases are likely to be evident elsewhere. Reforms aimed at increasing the autonomy of regional governments over broad-based taxes, as in Belgium and Spain, will likely create pro-cyclical revenue streams. Yet in most European countries, serious tax decentralization is not on the agenda, and an enhanced expenditure role for subnational governments is driven by intergovernmental grants or shared revenues. There are no reasons to expect central government grants to help subnational governments smooth expenditures over their business cycles. In Italy, for instance, weak regional revenue bases combine with an extensive system of rather volatile discretionary grants. Even among local governments in Finland, France, and Austria, extensive expenditure decentralization is financed in large part through intergovernmental grants over which the central government has considerable discretion, raising the potential for the kind of strategic burden-shifting discussed in this paper. In the unlikely event that the EMU Stability and Growth Pact was strictly enforced, European central governments might even begin to resemble some of the credit-constrained subnational governments examined in this paper, creating further incentives for overall pro-cyclicality.

In rapidly decentralizing developing countries as well, there is a danger that decentralization will heighten overall pro-cyclicality, especially of health, education, and social expenditures. Since it is often extremely difficult to fire workers, whose salaries make up the 
lion's share of subnational budgets, expenditures on such programs are likely to suffer during recessions. Potential steps to dampen the pro-cyclicality of subnational finance in decentralizing countries include finding less volatile tax sources, taking steps to insulate grants from short-term political calculations, and creating incentives for subnational governments to save during good times. A final option—enhancing independent subnational borrowing autonomy—is being taken off the table in many decentralizing countries. As European countries attempt to bring overall deficits in line with EMU criteria and developing countries attempt to avoid or recover from bouts of subnational over-borrowing, countries are scrambling to adopt golden rules, deficit limits, national stability pacts, and other constraints that limit the borrowing authority of subnational governments. 


\section{Acknowledgments}

This research was supported by the National Science Foundation, Grant SES-0241523

\section{References}

Alesina, Alberto and Tamim Bayoumi. 1996. "The Costs and Benefits of Fiscal Rules: Evidence from the U.S. States.” NBER Working Paper No. 5614. Cambridge: National Bureau of Economic Research.

Alesina, Alberto and Roberto Perotti. 1999. "Budget Deficits and Budget Institutions.” In Poterba, James M. and Jurgen von Hagen, eds. Fiscal Institutions and Fiscal Performance. Chicago: University of Chicago Press.

Alt, James E., David Dreyer Lassen, and David Skilling. 2001. "Fiscal Transparency and Fiscal Policy Outcomes in OECD Countries." Presented at the 2001 Annual Meeting of the Midwest Political Science Association.

Arreaza, Adriana, Bent E. Sorensen, and Oved Yosha. 1999. "Consumption Smoothing through Fiscal Policy in OECD and EU Countries.” In James Poterba and Jürgen von Hagen, eds. Fiscal Institutions and Fiscal Performance. Chicago: University of Chicago Press.

Asdrubali, Pierfederico, Bent E Sorensen, and Oved Yosha. 1996. "Channels of Interstate Risk Sharing: United States 1963-1990.” Quarterly Journal of Economics 111(4): 1081-1110.

Balassone, Fabrizio, Daniele Franco, and Stefania Zotteri. 2002. "Fiscal Rules for Subnational Governments: What Lessons from EMU Countries?” Prepared for the Conference on 'RulesBased Macroeconomic Policies in Emerging Market Economies' organised by the IMF and the World Bank, Oaxaca - Mexico, February 14-16 2002.

Bayoumi, Tamim and Paul Masson. 1996. "What Can the Fiscal Systems in the United States and Canada Tell Us about EMU?” European Monetary Integration: EMS developments and international post-Maastricht perspectives: 307-31.

Brunila, Anne, Marco Buti and Jan in't Veld. 2002. 'Fiscal Policy in Europe: How Effective are Automatic Stabilisers?', European Economy, Economic Papers no. 177.

Dillinger, William and Steven Webb 1999. "Fiscal Management in Federal Democracies: Argentina and Brazil.” Empirica 45(3): 423-83.

EC (European Commission). 2003. Public Finances in EMU, 2003. Brussels: European Commission.

Emiliani, Nicoletta, Sergio Lugaresi, and Edgardo Ruggiero. 1997. "Italy.” In Ter-Minassian, Teresa ed. Fiscal Federalism in Theory and Practice. Washington, DC: International Monetary Fund.

Gérard, Marcel. 2001. “Fiscal Federalism in Belgium.” Paper presented at the Conference on Fiscal Imbalance, Québec City, September 13-14, 2001 
Gramlich, Edward M. 1976. "Intergovernmental Grants: A Review of the Empirical Literature.” In Wallace Oates, ed. The Political Economy of Fiscal Federalism. Lexington: Lexington Books.

Hallerberg, Mark and Rolf Strauch. 2002. "On the Cyclicality of Public Finances in Europe.” Empirica 29: 183-207.

International Monetary Fund. 2003. Global Financial Stability Report. Washington DC: International Monetary Fund.

Kletzer, Kenneth M and Jürgen von Hagen. 2000. "Monetary Union and Fiscal Federalism.” CEPR Discussion Paper 2615.

Knott, Jack. 1976. "Stabilization Policy, Grants-in-aid, and the Federal System in Germany.” In Wallace Oates, ed. The Political Economy of Fiscal Federalism. Lexington: Lexington Books.

Melitz, Jacques and Frederic Zumer. 1998. "Regional Redistribution and Stabilization by the Centre in Canada, France, the United Kingdom and the United States: New Estimates Based on Panel Data Econometrics.” CEPR Discussion Paper 1829.

Musgrave, Richard. 1959. The Theory of Public Finance: A Study of Public Economy. New York: McGraw-Hill Book Company, Inc.

Norregaard, John. 1997. “Tax Assignment.” In Ter-Minassian, Teresa ed. Fiscal Federalism in Theory and Practice. Washington, DC: International Monetary Fund.

Oates, Wallace E. 1972. Fiscal Federalism. New York: Hartcourt Brace Jovanovich.

Obstfeld, Maurice and Giovanni Peri. 1998. "Regional Non-adjustment and Fiscal Policy.” Economic Policy: A European Forum 26: 205-47.

Persson, Torsten and Guido Tabellini. 2001. "Political Institutions and Policy outcomes: What are the Stylized Facts?” Mimeo, Bocconi University.

Poterba, James. 1994. "State Responses to Fiscal Crises: The Effects of Budgetary Institutions and Politics.” Journal of Political Economy 102: 798-821.

Poterba, James and Juergen von Hagen, eds. 1999. Fiscal Institutions and Fiscal Performance. Chicago: University of Chicago and National Bureau of Economic Research.

Rodden, Jonathan. 2004. "Comparative Federalism and Decentralization: On Meaning and Measurement.” Comparative Politics 36(4): 481-500.

Rodden, Jonathan. 2005. "And the Last shall be First: Federalism and Soft Budget Constraints in Germany.” Unpublished paper, MIT.

Sala-i-Martin, Xavier and Jeffrey Sachs. 1992. "Fiscal Federalism and Optimum Currency Areas: Evidence for Europe from the United States.” CEPR Discussion Paper 632.

Seitz, Helmut. 2000. "Fiscal Policy, Deficits and Politics of Subnational Governments: The Case of the German Laender.” Public Choice 102(3-4): 183-218. 
Sorensen, Bent E., Lisa Wu, and Oved Yosha. 2001. "Output Fluctuations and Fiscal Policy: US State and Local Governments 1978-1994.” European Economic Review 45: 1271-1310.

Tornell, Aaron and Philip Lane. 1999. "The Voracity Effect.” American Economic Review 89: 22-46.

Treisman, Daniel. 2000. "Decentralization and Inflation: Commitment, Collective Action, or Continuity?" American Political Science Review 94: 837-858.

Van den Noord, Paul. 2000. "The Size and Role of Automatic Fiscal Stabilizers in the 1990s and Beyond.” OECD Economics Department Working Paper No. 230.

van Wincoop, Eric. 1995. “Regional Risksharing.” European Economic Review 39(8): 1545-67.

Velasco, Andres. 2000. “Debts and Deficits with Fragmented Fiscal Policymaking.” Journal of Public Economics 76(1): 105-25.

von Hagen, Jürgen. 1992. “Policy-Delegation and Fixed Exchange Rates.” International Economic Review 33(4): 849-70.

von Hagen, Jürgen and Ralf Hepp. 2001. "Regional Risk Sharing and Redistribution in the German Federation.” CEPR Discussion Paper 2662.

Wibbels, Erik. 2004. "Dependency Revisited: International Markets, Business Cycles, and Social Spending in the Developing World.” Working Paper, University of Washington Department of Political Science. 
Table 1: Income elasticities for provincial budget items

\begin{tabular}{|c|c|c|c|c|c|c|c|c|}
\hline & & Revenue & $\begin{array}{l}\text { Own-source } \\
\text { revenue }\end{array}$ & Grants & $\begin{array}{l}\text { Revenue-sharing } \\
\text { receipts }\end{array}$ & $\begin{array}{l}\text { Discretionary } \\
\text { grants }\end{array}$ & Expenditures & Surplus \\
\hline \multirow{2}{*}{ U.S. states } & without year dummies & $0.68^{* * *}$ & 0.84 * & 0.42 & \multirow{2}{*}{ na } & \multirow{2}{*}{ na } & $0.37 * \star \star$ & $0.05^{* * *}$ \\
\hline & including year dummies & 0.53 *** & 0.8 * & $-0.25 *$ & & & $0.34 * \star \star$ & $0.04^{* * *}$ \\
\hline \multirow{2}{*}{ Canadian provinces } & without year dummies & 0.89 *** & 1.05 * & 0.41 & \multirow{2}{*}{ na } & \multirow{2}{*}{ na } & $0.39 * \star$ & $0.13^{* * *}$ \\
\hline & including year dummies & $0.77^{* * *}$ & 1.15 * & -0.68 * & & & $x$ & 0.22 *** \\
\hline \multirow{2}{*}{ German Länder } & without year dummies & 1.01 *** & \multirow{2}{*}{ na } & 1.09 * & \multirow{2}{*}{ na } & \multirow{2}{*}{ na } & 0.57 *** & 0.22 \\
\hline & including year dummies & $0.43^{* * *}$ & & -0.92 & & & 0.76 *** & $x$ \\
\hline \multirow{2}{*}{ Australian states } & without year dummies & $0.78^{* * *}$ & 1.60 * & $x$ & \multirow{2}{*}{ na } & \multirow{2}{*}{ na } & $x$ & 0.20 * \\
\hline & including year dummies & $0.87^{* * *}$ & 1.23 * & 0.84 * & & & -0.69 & 0.48 *** \\
\hline Spanish aut. & without year dummies & $2.56 * \star \star x$ & 5.75 * & 4.22 * & \multirow{2}{*}{ na } & \multirow{2}{*}{ na } & $1.71 * \star$ & 1.66 \\
\hline Communities & including year dummies & 0.81 * & 4.22 * & $x$ & & & $x$ & $2.02 * *$ \\
\hline \multirow{2}{*}{ Indian states } & without year dummies & 0.42 * & $\mathrm{x}$ & $\mathrm{x}$ & $\mathrm{x}$ & $\mathrm{x}$ & $0.67 \star \star \star *$ & $x$ \\
\hline & including year dummies & 0.25 & $x$ & $x$ & $x$ & $x$ & $0.67 * * *$ & $x$ \\
\hline \multirow{2}{*}{ Brazilian states } & without year dummies & 1.62 *** & 2.06 * & 1.56 * & $x$ & 7.58 *** & $1.67 * \star \star$ & $x$ \\
\hline & including year dummies & $1.03^{* * *}$ & 1.65 * & 0.52 * & $-1.48 * * *$ & 4.6 & 1.26 *** & $-0.01 *$ \\
\hline \multirow{2}{*}{ Argentine provinces } & without year dummies & 0.36 ** & 1.15 * & 0.30 * & 0.38 * & $x$ & $0.30 * \star *$ & $x$ \\
\hline & including year dummies & $0.10 *$ & $0.51 *$ & $0.09 *$ & 0.15 & 1.07 * & $\mathrm{x}$ & 0.01 \\
\hline
\end{tabular}

Percent deviation from trend in budget item was regressed on percent deviation from trend in provincial income, including fixed provincial effects, assuming ar1 correlation of residuals. Only coefficients where $p<.25$ are reported. Where $p>.25$, the cell contains an $x$. "NA" indicates that appropriate data were unavailable.

$* p<.1$

$* * p<.05$

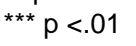


Table 2: Responses of provincial budget items to positive and negative shocks

\begin{tabular}{|c|c|c|c|c|c|c|c|c|c|c|c|c|c|}
\hline & & \multicolumn{2}{|c|}{ Revenue } & \multicolumn{3}{|c|}{ Own-source revenue } & \multicolumn{3}{|c|}{ Grants } & \multicolumn{2}{|c|}{ Revenue-sharing receipts } & \multicolumn{2}{|c|}{ Discretionary grants } \\
\hline & & Pos. shock & Neg. shock & & Pos. shock & Neg. shock & Pos. shock & Neg. S & shock & Pos. shock & Neg. shock & Pos. shock & Neg. shock \\
\hline U.S. states & $\begin{array}{l}\text { without year dummies } \\
\text { including year dummies }\end{array}$ & $\begin{array}{l}0.52^{* *} \\
0.61 \text { ** }\end{array}$ & $\begin{array}{l}0.85 * \\
0.43 *\end{array}$ & & $\begin{array}{l}0.87^{* * *} \\
0.91 * * *\end{array}$ & $\begin{array}{l}0.81 * * \\
0.65 * \star\end{array}$ & $\begin{array}{c}x \\
-0.29 \text { * }\end{array}$ & & ${ }_{\mathrm{x}}^{1.08}$ & na & & na & \\
\hline $\begin{array}{l}\text { Canadian } \\
\text { provinces }\end{array}$ & $\begin{array}{l}\text { without year dummies } \\
\text { including year dummies }\end{array}$ & $\begin{array}{l}0.43^{* *} \\
0.76^{* *}\end{array}$ & $\begin{array}{r}1.6 * \\
0.78 *\end{array}$ & & $\begin{array}{r}0.45^{* *} \\
1 * * *\end{array}$ & $\begin{array}{l}1.99^{* \star} \\
1.33^{* \star}\end{array}$ & $\begin{array}{l}\mathrm{x} \\
\mathrm{x}\end{array}$ & & $\begin{array}{c}\mathrm{x} \\
-1.26 \text { *** }\end{array}$ & na & & na & \\
\hline German Länder & $\begin{array}{l}\text { without year dummies } \\
\text { including year dummies }\end{array}$ & $\begin{array}{r}0.66 \text { *** } \\
0.4 \text { ** }\end{array}$ & $\begin{array}{l}1.18 * \\
0.54 *\end{array}$ & & $\mathrm{n}$ & ha & $\frac{1.77 \text { * }}{x}$ & & $\begin{array}{c}x \\
-2.2\end{array}$ & na & & na & \\
\hline Australian states & $\begin{array}{l}\text { without year dummies } \\
\text { including year dummies }\end{array}$ & $\begin{array}{l}x \\
x\end{array}$ & $\begin{array}{l}1.56 \\
1.36\end{array}$ & & $\begin{array}{l}x \\
x\end{array}$ & $\begin{array}{l}2.43^{* \star} \\
2.06 \text { ** }\end{array}$ & $\begin{array}{l}\mathrm{x} \\
\mathrm{x}\end{array}$ & & $\begin{array}{c}x \\
1.23\end{array}$ & na & & na & \\
\hline $\begin{array}{l}\text { Spanish aut. } \\
\text { communities }\end{array}$ & $\begin{array}{l}\text { without year dummies } \\
\text { including year dummies }\end{array}$ & $\begin{array}{r}1.89 \\
\times\end{array}$ & $\begin{array}{l}3.33 \\
1.62\end{array}$ & & $\begin{array}{r}4.29 \\
\times\end{array}$ & $\begin{array}{c}7.53 \text { ** } \\
4.6 \text { * }\end{array}$ & $\begin{array}{r}5.23 \\
\times\end{array}$ & & $\begin{array}{l}\mathrm{x} \\
\mathrm{x}\end{array}$ & na & & na & \\
\hline Indian states & $\begin{array}{l}\text { without year dummies } \\
\text { including year dummies }\end{array}$ & $\begin{array}{l}x \\
x\end{array}$ & $\begin{array}{l}0.67 \\
0.61\end{array}$ & & $\begin{array}{l}x \\
x\end{array}$ & $\begin{array}{l}x \\
x\end{array}$ & $\begin{array}{r}-1.5 \\
\times\end{array}$ & $\mathrm{x}$ & 1.5 & $\begin{array}{l}x \\
x\end{array}$ & $\begin{array}{l}x \\
x\end{array}$ & $\begin{array}{l}\mathrm{x} \\
\mathrm{x}\end{array}$ & $\underset{x}{2.16}$ * \\
\hline Brazilian states & $\begin{array}{l}\text { without year dummies } \\
\text { including year dummies }\end{array}$ & $\begin{array}{l}1.62 \text { ** } \\
1.16^{* *}\end{array}$ & $\begin{array}{l}1.85 \\
1.05\end{array}$ & & $\begin{aligned} 2.3 * \star * \\
1.89^{* \star *}\end{aligned}$ & $\begin{array}{r}2.05^{* \star} \\
1.6^{* \star}\end{array}$ & $\begin{array}{l}1.52 * * * \\
0.76 \text { * }\end{array}$ & & $\begin{array}{c}1.59 * * * \\
x\end{array}$ & $\begin{array}{l}x \\
x\end{array}$ & $\begin{array}{c}x \\
-2.2^{* * *}\end{array}$ & $\begin{array}{l}x \\
x\end{array}$ & $\begin{array}{r}14 \text { *** } \\
12.3 * \star *\end{array}$ \\
\hline $\begin{array}{l}\text { Argentine } \\
\text { provinces }\end{array}$ & $\begin{array}{l}\text { without year dummies } \\
\text { including year dummies }\end{array}$ & $\begin{array}{l}0.52^{* *} \\
0.24^{* *}\end{array}$ & $\begin{array}{l}x \\
x\end{array}$ & & $\begin{array}{l}0.94^{* * *} \\
1.48^{* * *}\end{array}$ & $\begin{array}{r}x \\
0.76\end{array}$ & $\begin{array}{c}0.4 * \\
0.19 * *\end{array}$ & & $\begin{array}{l}x \\
x\end{array}$ & $\begin{array}{l}x \\
x\end{array}$ & $\begin{array}{c}0.66 \text { ** } \\
x\end{array}$ & $\begin{array}{l}4.28 \text { ** } \\
1.83 \text { * }\end{array}$ & $\begin{array}{l}x \\
x\end{array}$ \\
\hline & & $\frac{\text { Expenc }}{\text { Pos. Shock }}$ & $\frac{\text { ditures }}{\text { Neg. shock }}$ & & $\frac{\text { Surpl }}{\text { Pos. shock }}$ & lus & & & & & & & \\
\hline U.S. states & $\begin{array}{l}\text { without year dummies } \\
\text { including year dummies }\end{array}$ & $\begin{array}{c}x \\
0.34\end{array}$ & $\begin{array}{l}0.59 \\
0.34\end{array}$ & $* * *$ & $\begin{array}{l}0.04^{* *} \\
0.03\end{array}$ & $\begin{array}{l}0.08^{* *} \\
0.06 \text { ** }\end{array}$ & & & & & & & \\
\hline $\begin{array}{l}\text { Canadian } \\
\text { provinces }\end{array}$ & $\begin{array}{l}\text { without year dummies } \\
\text { including year dummies }\end{array}$ & $\begin{array}{l}x \\
x\end{array}$ & $\begin{array}{l}1.02 \\
0.27\end{array}$ & 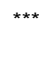 & $\begin{array}{l}0.10^{* *} \\
0.23^{* * *}\end{array}$ & $\begin{array}{l}0.18 \text { ** } \\
0.20 \text { ** }\end{array}$ & & & & & & & \\
\hline German Länder & $\begin{array}{l}\text { without year dummies } \\
\text { including year dummies }\end{array}$ & $\begin{array}{l}0.83^{* *} \\
0.76^{* *}\end{array}$ & $\begin{array}{r}x \\
0.75\end{array}$ & $* \star \star$ & $\begin{array}{l}x \\
x\end{array}$ & $\underset{x}{0.42 * *}$ & & & & & & & \\
\hline Australian states & $\begin{array}{l}\text { without year dummies } \\
\text { including year dummies }\end{array}$ & $\begin{array}{l}x \\
x\end{array}$ & $\begin{array}{l}x \\
x\end{array}$ & & $\begin{array}{c}x \\
0.43^{* *}\end{array}$ & $\begin{array}{l}0.51^{* *} \\
0.54^{* *}\end{array}$ & & & & & & & \\
\hline $\begin{array}{l}\text { Spanish aut. } \\
\text { communities }\end{array}$ & $\begin{array}{l}\text { without year dummies } \\
\text { including year dummies }\end{array}$ & $\begin{array}{r}1.84 \\
\times\end{array}$ & $\begin{array}{l}x \\
x\end{array}$ & & $\begin{array}{l}\mathrm{x} \\
\mathrm{x}\end{array}$ & $\begin{array}{r}x \\
4.99\end{array}$ * & & & & & & & \\
\hline Indian states & $\begin{array}{l}\text { without year dummies } \\
\text { including year dummies }\end{array}$ & $\begin{array}{l}x \\
x\end{array}$ & $\begin{array}{l}1.13 \\
1.22\end{array}$ & $\begin{array}{l}* * * \\
* * *\end{array}$ & $\begin{array}{l}x \\
x\end{array}$ & $\begin{array}{l}x \\
x\end{array}$ & & & & & & & \\
\hline Brazilian states & $\begin{array}{l}\text { without year dummies } \\
\text { including year dummies }\end{array}$ & $\begin{array}{l}1.62 * * \\
1.28 *\end{array}$ & $\begin{array}{l}1.72 \\
1.23\end{array}$ & $\begin{array}{l}* \star \star \\
\star \star \star\end{array}$ & $\begin{array}{l}x \\
x\end{array}$ & $\begin{array}{c}x \\
-0.02 * *\end{array}$ & & & & & & & \\
\hline $\begin{array}{l}\text { Argentine } \\
\text { provinces }\end{array}$ & $\begin{array}{l}\text { without year dummies } \\
\text { including year dummies }\end{array}$ & $\begin{array}{l}0.41 \text { ** } \\
0.13\end{array}$ & $\begin{array}{r}x \\
-0.17\end{array}$ & & $\begin{array}{l}\mathrm{x} \\
\mathrm{x}\end{array}$ & $\begin{array}{l}x \\
x\end{array}$ & & & & & & & \\
\hline
\end{tabular}


Figure 1: Responses of budget items to innovations in gross state product

U.S: Effect on State Budget of a 1\% Permanent Increase in GSP

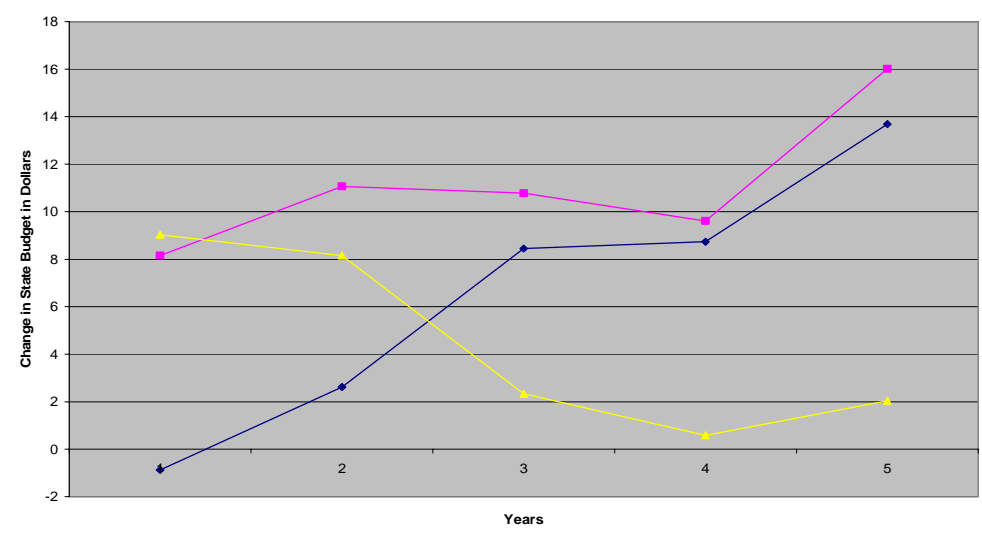

$\rightarrow$-spending $\rightarrow$ - revenue $\rightarrow$ surplus

Spain: Effect on State Budget of a $1 \%$ Permanent Increase in GSP

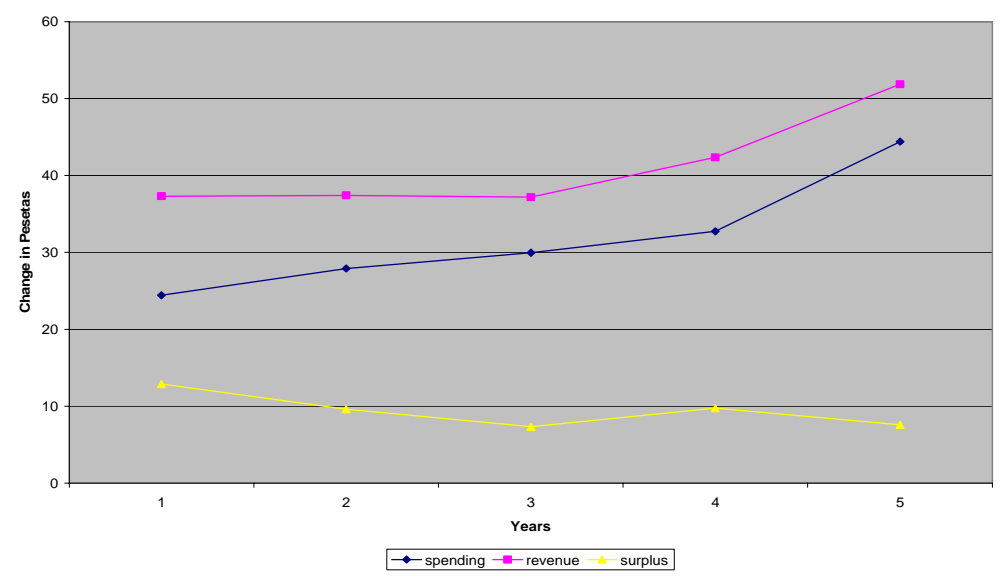

Canada: Effect on State Budget of a $1 \%$ Permanent Increase in GSP

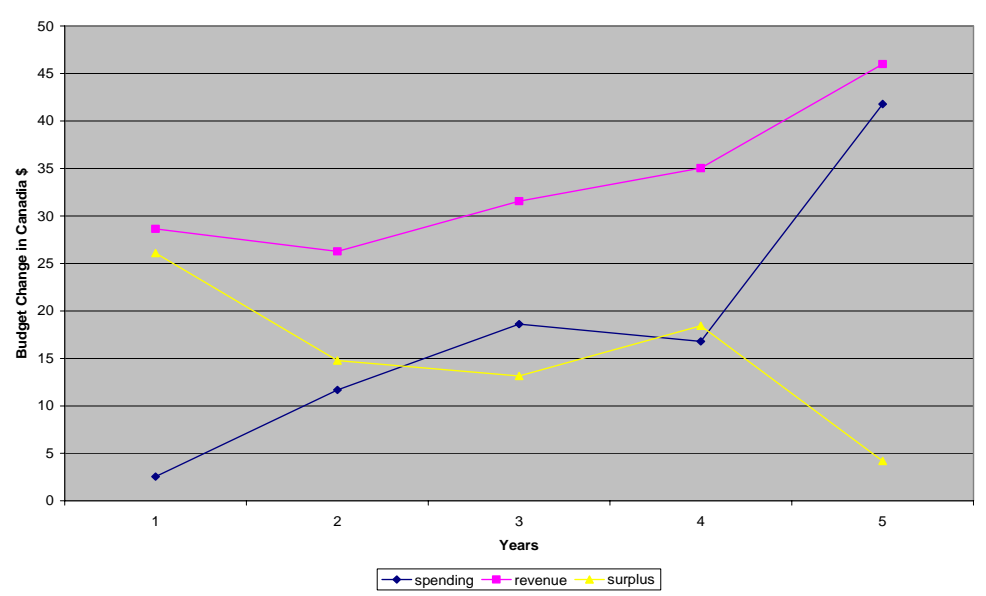

Australia: Effect on State Budget of a 1\% Permanent Increase in GSP

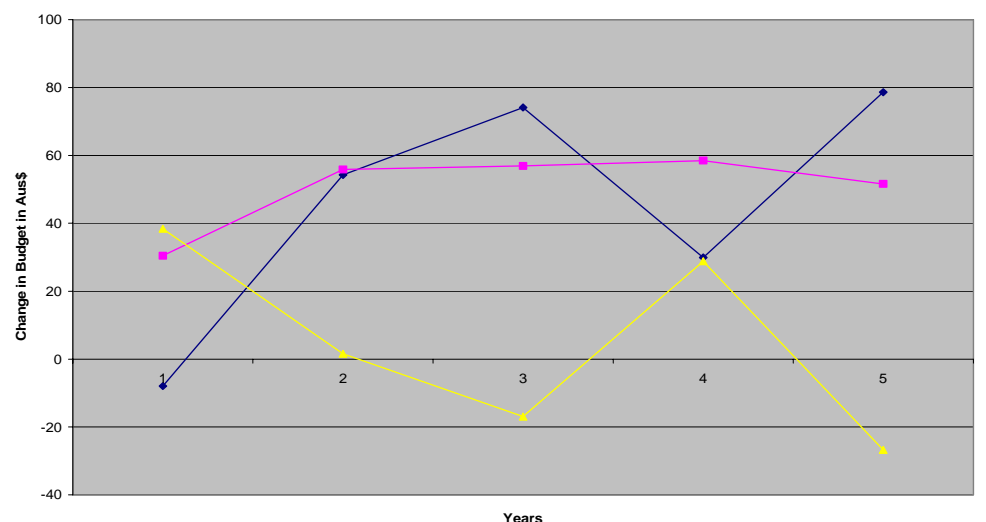

$\rightarrow$-spending $\rightarrow-$-revenue $\rightarrow$-surplus 
Figure 1 (continued): Responses of budget items to innovations in gross state product

Argentina: Effect on State Budget of a $1 \%$ Permanent Increase in GSP

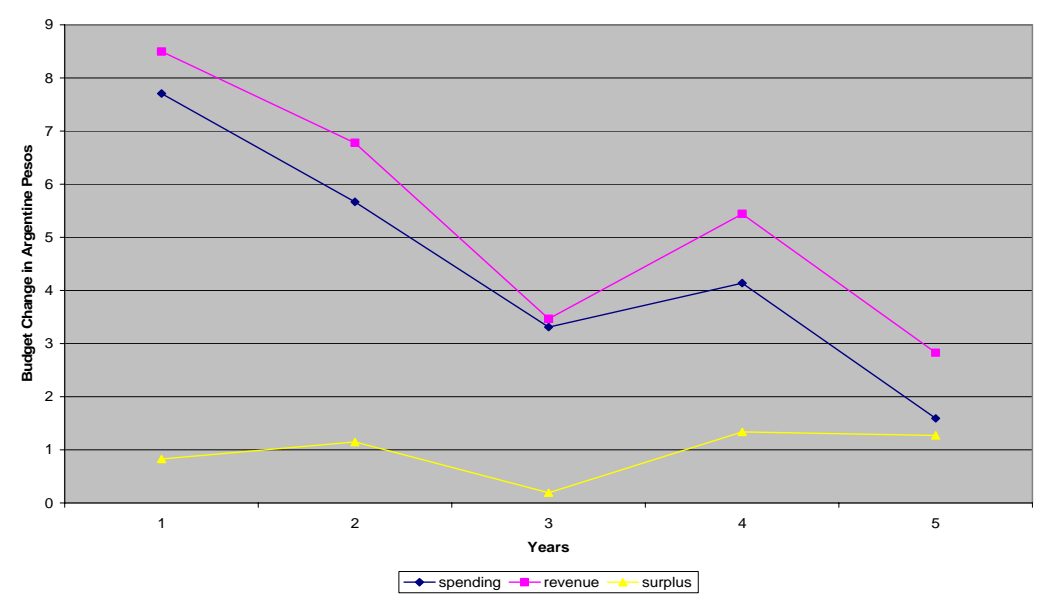

Germany: Effect on State Budget of a 1\% Permanent Increase in GSP

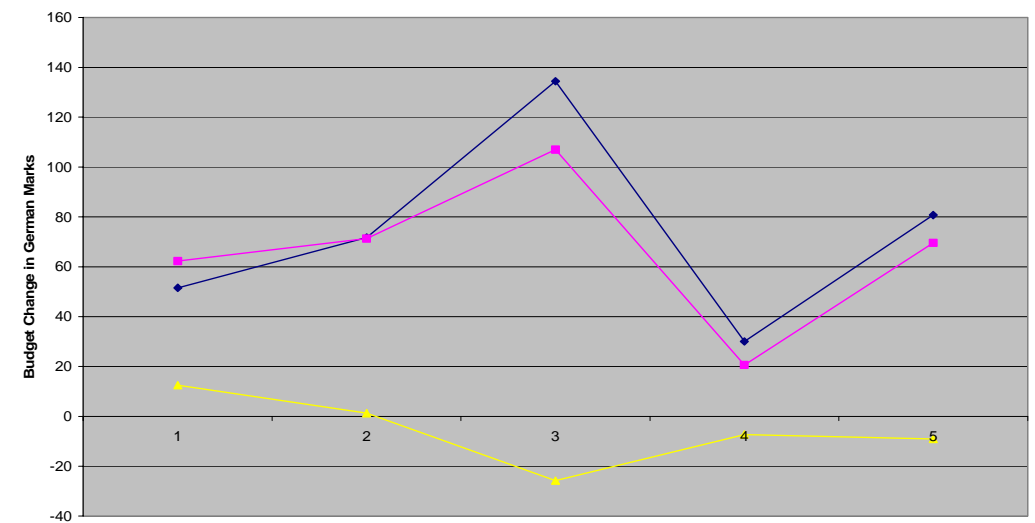

Years
\[ - \text { spending }-m-\text { revenue } \rightarrow \text { surplus } \]
Brazil: Effect on State Budget of a 1\% Permanent Increase in GSP

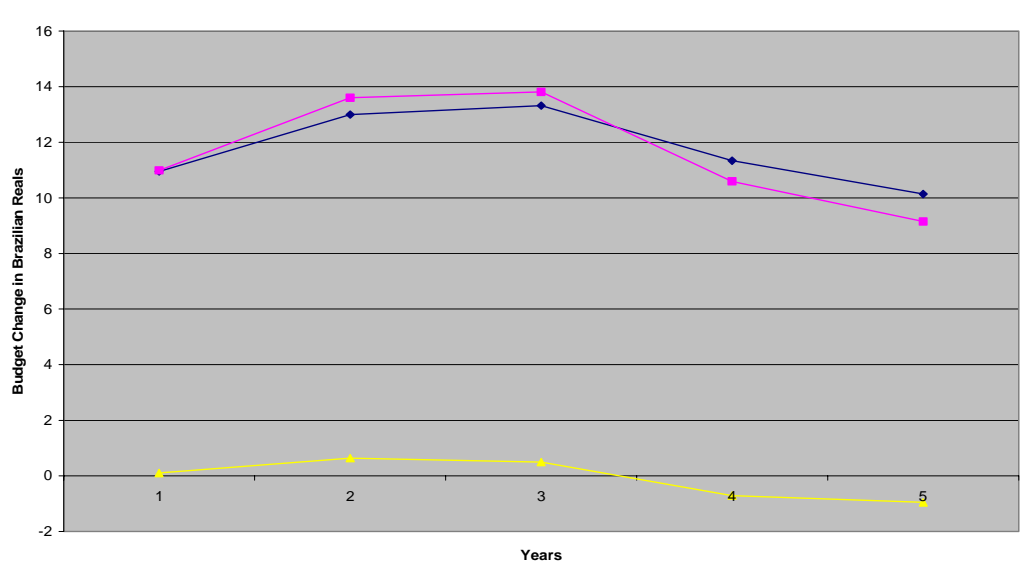

$\underset{- \text { spending }- \text {-revenue } \quad \text { surplus }}{\text { Years }}$

India: Effect on State Budget of a $1 \%$ Permanent Increase in GSP

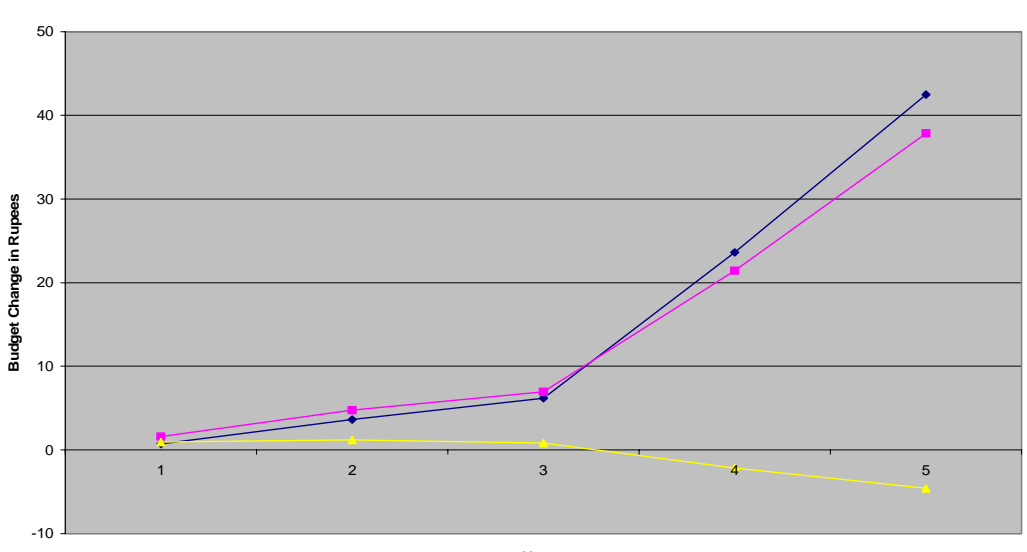

Years

$\rightarrow$-spending $\rightarrow-$-revenue $\rightarrow$ surplus 
